TAPROBANICA, ISSN 1800-427X. May, 2020. Vol. 09, No. 01: pp. 59-70, pls. 22-24. (C) Research Center for Climate Change, University of Indonesia, Depok, Indonesia www.taprobanica.org

\title{
A NEW BENT-TOED GECKO SPECIES OF THE GENUS Cyrtodactylus GRAY, 1827 (SQUAMATA: GEKKONIDAE) FROM THE WEST BALI NATIONAL PARK, BALI, INDONESIA
}

\author{
A. A. Thasun Amarasinghe ${ }^{1,4}$, Awal Riyanto ${ }^{2}$ Mumpuni $^{2} \&$ Lee L. Grismer ${ }^{3}$ \\ ${ }^{1}$ Research Center for Climate Change, University of Indonesia, Gd. PAU Lt. 8.5, Kampus UI, Depok 16424, \\ Indonesia \\ ${ }^{2}$ Museum Zoologicum Bogoriense (MZB), Research Center for Biology, Indonesian Institute of Sciences (LIPI), \\ Jl. Raya Jakarta Bogor Km. 46 Cibinong West Java Indonesia 16911 \\ ${ }^{3}$ Department of Biology, La Sierra University, 4500 Riverwalk Parkway, Riverside, California 92515, USA \\ ${ }^{4}$ Association of Asian Herpetology (Asosiasi Herpetologi Asia), Jl. BSD Bintaro No. 88, Pondok Aren 15228, \\ Tangerang Selatan, Indonesia \\ ${ }^{1}$ Corresponding author. E-mail: thasun@rccc.ui.ac.id
}

\begin{abstract}
A new bent-toed gecko species of the genus Cyrtodactylus is described herein from West Bali National Park on the island of Bali, Indonesia. The Cyrtodactylus from Bali have been recognized as C. fumosus for nearly a century. However, recent detailed examination of the type material of $C$. fumosus has revealed that Balinese Cyrtodactylus represent at least one different species. A morphological examination of the new species and samples from different biogeographic regions revealed that the new species is similar to C. seribuatensis from Pulau Seribuat in West Malaysia. Morphologically, the new species can be distinguished from its congener by having 40-43 femoroprecloacal pores (vs 10-12 precloacal pores, 14-16 femoral pores), 40-48 ventral scales between ventrolateral folds ( $v s 28-39), 24-29$ rows of dorsal tubercles (vs 27-35), and presence of tubercles on lateral skinfold ( $v s$ absent).
\end{abstract}

Key words: Cyrtodactylus fumosus, Sundaland, taxonomy, Taman Nasional Bali Barat

\section{Introduction}

The island of Bali, or Pulau Dewata in Indonesian, is one of world's most popular tourist destinations with one of the region's richest cultural histories. Its importance to biogeography and biodiversity has been known ever since Alfred Russel Wallace documented a faunal shift when crossing the Lombok Strait from Bali to neighboring Lombok (Wallace 1868), a distance of only $35 \mathrm{~km}$. In Wallace's honor, the imaginary line separating these islands and their faunas was named Wallace's Line (Huxley 1868; Barbour 1912), and the biogeographic region that extends east beyond Bali into the Indonesian island archipelago has become known as Wallacea (Beccaloni 2015, 
Marzuki \& Andili 2015). However, with the development of tourism and Bali's standing as a staging ground for expeditions to outlying areas, Bali itself has been somewhat overlooked as an island with potentially high diversity and endemism. Bali Island $\left(5,780 \mathrm{~km}^{2}\right)$ is geologically part of a volcanic island arc that includes the Greater and Lesser Sunda Islands. The main, northern portion of the island was created over a period of time by the eruptions of undersea volcanoes, and it probably surfaced about 3 million years ago (McKay 2006). Bali's fauna and flora are generally most closely allied with that of neighboring Java. Java is a much larger island $\left(128,297 \mathrm{~km}^{2}\right)$ formed by an eastwest series of volcanoes and sedimentary accretions, and separated from Bali only by the narrow (3 km) Bali Strait (Whitten et al. 1996). Based on Bathymetric Map number 290 at a scale of 1:200,000, edition of March 2006, the Bali Strait is shallow in its narrowest part with an average depth of about $50 \mathrm{~m}$, and deeper at its northern and southern ends where depths range from 100 to $800 \mathrm{~m}$ (Berlianty \& Yanagi 2011). The herpetofauna of Bali is under the influence of the humid climate of Southeast Asia and the Greater Sunda Islands, and the generally drier weather patterns along the Lesser Sunda chain. It has been suggested that for some species, the genetic difference between the Balinese populations and those of the Greater Sundas may indicate that the populations on Bali have been isolated for a substantially long period of time, although, the sea passage between East Java and Bali is narrow and should not hinder species migration (Amarasinghe et al. 2017). The most recent herpetofaunal checklists of Bali (e.g. McKay 2006, Riyanto \& Mumpuni 2013) include only one species of bent-toed gecko, Cyrtodactylus fumosus (Müller, 1895). Recent investigations into the taxonomy of Cyrtodactylus in Indonesia (Hartmann et al. 2016, Harvey et al. 2015, Riyanto et al. 2015a,b, 2016, 2017, 2018a,b) documented evidence that the Cyrtodactylus fauna is probably far more diverse than the current species counts would indicate. A detailed re-examination of $C$. fumosus s. str. by Mecke et al. (2016a) revealed that our specimens from Bali represent an unnamed species, which we here regard as a valid new species of the genus Cyrtodactylus.

\section{Materials and methods}

We collected the type series by hand, euthanized the specimens with sodium pentobarbital or trichloromethane, and fixed the specimens in $10 \%$ buffered formalin prior to storage in $70 \%$ ethanol. We preserved tissue samples for DNA analysis in $96 \%$ ethanol. We compared specimens of the new species to specimens and original descriptions of close congeners. Museum acronyms are those of Uetz et al. (2019). Specimens of the new species were examined at the Museum of Zoology, Research Center for Climate Change, University of Indonesia (UIMZ) and are currently deposited at Museum Zoologicum Bogoriense, Cibinong, Indonesia (MZB). Measurements and scale counts were made on the right side of each specimen. To visualize some structures, such as subdigital lamellae or pores, we used the reversible staining technique with methylene blue in 70\% alcohol (Amarasinghe et al. 2015). Sex was determined as male if (1) preserved specimens showed enlarged hemipenial pockets, and confirmed by (2) viewing the hemipenes via a small lateral incision made at the base of the tail. All measurements were made after specimens had been fixed in $10 \%$ buffered formalin and subsequently stored in $70 \%$ ethanol. Under an AmScope / Leica Wild M3Z dissecting microscope, with a Mitutoyo digital caliper to the nearest $0.1 \mathrm{~mm}$, we measured snout-vent length (SVL, measured from tip of snout to vent), tail length (TL, measured from vent to tip of tail), head length (HL, distance from tip of snout to posterior edge of retroarticular process of lower jaw), head width (HW, measured a straight line at angle of jaws), head depth (HD, maximum height of head between occiput and throat), snout length (ES, measured from tip of snout to anterior most edge of orbit), eye-nostril length (EN, from anterior border of orbit to posterior border of nostril), tympanum-eye length (TYE, measured from edge of orbit to anterior edge of ear opening), tympanum diameter (TYD, maximum length of ear opening), orbit diameter (OD, horizontal diameter of orbit), forearm length (FAL, taken on dorsal surface from posterior margin of elbow while flexed at $90^{\circ}$ to inflection of dorsally flexed wrist), femur length (FEL, from the anterior margin of the hind limb at its insertion point on the body to the knee while flexed), and tibia length (TBL, measured on ventral surface from posterior surface from posterior surface of knee while flexed at $90^{\circ}$ to base of the heel).

Further, under an AmScope microscope or a Leica Wild M3Z dissecting microscope we 
counted supralabial scales (from largest scale immediately posterior to dorsal inflection of posterior portion of upper jaw to the rostral scales), infralabial scales (number of labial scales of lower jaw, beginning with first scale bordering mental shield, ending with last enlarged scale bordering labial angle), enlarged precloacofemoral scales (number of enlarged precloacofemoral scales along lowest porebearing row), dorsal tubercles (number of longitudinal tubercles rows on dorsum at midbody between ventrolateral folds), paravertebral tubercles (tubercles between postaxial margin of arm and preaxial margin of leg), ventral scales (number of ventral scales at midbody in one row between ventrolateral folds), number of scales under fingers/toes 1-5 [subdigital scales from point where interdigital skin contacts digit regardless of condition of scales under digit at this point, including fractured scales but not the elongate ungual scale at the base of the claw (claw sheath) or lamellae that extend onto the palm/ plantar surface at base of digit]. Basal subdigital scales were counted from the most proximal scale at least twice as large as adjacent palmar scales following Bauer et al. (2010).

We assessed the presence of tubercles on the dorsal surfaces of the brachium, antebrachium and thigh as well as the presence of enlarged transversely median subcaudals. We follow Kathriner et al. (2014) and Mecke et al. $(2016 a, b)$ to describe the morphology of precloacal depressions. Color notes were taken from digital images of living specimens prior to preservation. Latitude, longitude, and elevation of localities of specimens collected were recorded using a Garmin GPSmap 60CSx using WGS 84 map datum.

\section{Taxonomy}

Cyrtodactylus jatnai sp. nov.

(Figs. 1-4, Tables 1-3)

Cyrtodactylus fumosus-McKay 2006: 60

C. fumosus-Riyanto \& Mumpuni 2013: 6

Holotype. Adult male, MZB uncat. (UIMZ 0085), SVL $66.8 \mathrm{~mm}$, collected from Teluk Menjangan, Taman Nasional Bali Barat, Bali, Indonesia $\left(08^{\circ} 08^{\prime} 38.6^{\prime \prime} \mathrm{S}, 114^{\circ} 32^{\prime} 22.5^{\prime \prime} ; 20 \mathrm{~m}\right.$ a.s.1.), by A.A. Thasun Amarasinghe, on 26-27 August 2015.

Paratypes $(n=18)$. Adult male, MZB uncat. (UIMZ 0082); adult female, MZB uncat. (UIMZ 0084); subadult male, MZB uncat. (UIMZ
0083); collected from Mt. Lannying, Taman Nasional Bali Barat, Bali, Indonesia, other details same as holotype; adult male, MZB uncat. (UIMZ 0101); subadult males, MZB uncat. (UIMZ 0093, 0102); collected from Teluk Brumbun, Taman Nasional Bali Barat, Bali, Indonesia, other details same as holotype; adult males, MZB 8729, 8731; adult female MZB 8728; subadult males (MZB 8730, 8732, 8735); subadult females (MZB 8727, 8733, 8734); collected from Teluk Terima, Taman Nasional Bali Barat, Bali, Indonesia, by A. Riyanto, Mumpuni \& Mulyadi on 11-15 April 2012; adult male (MZB 8726); adult female (MZB 8725); collected from Gerojogan, Taman Nasional Bali Barat, Bali, Indonesia, other details same as above; adult female (MZB 8737) collected from Teluk Menjangan, Taman Nasional Bali Barat, Bali, Indonesia, other details same as above.

Diagnosis. A combination of the following characters distinguishes the new species from all other Southeast Asian congeners: adult males reaching $66.8 \mathrm{~mm} \mathrm{SVL}$ and females $64.8 \mathrm{~mm}$ SVL; 9-11 supralabials; 8 or 9 infralabials; strongly tuberculated body and limbs, lateral fold with tubercles, tubercles on anterior portion of tail; tubercles extend from occiput to waist, and becoming larger tubercles posteriorly; 2429 dorsal tubercle rows; 40-48 rows of smooth ventrals; distinctly enlarged femoral scales in two rows, extending to precloacal region; 40-43 continuous femoro-precloacal pores in males; six rows of enlarged post precloacal scales; $17-$ 19 subdigital lamellae on the fourth toe; no enlarged median subcaudals; no reticulated pattern on head; paired dark blotches forming a V-shaped on occiput; dorsum blotched.

Description of holotype. Adult male, SVL 66.8 $\mathrm{mm}$, TL $82.5 \mathrm{~mm}$; head triangular, moderately long (HL/SVL 0.29) and wide (HW/HL 0.63), somewhat depressed (HD/HL 0.39), distinct from neck; lores weakly inflated, prefrontal region concave, canthus rostralis smoothly rounded; snout short (ES/HL 0.39) and rounded; eye large (OD/HL 0.32); ear opening oblong, small (TYD/HL 0.09); eye-ear length greater than diameter of eye (TYE/OD 0.70); rostral 1.6 times wider $(2.2 \mathrm{~mm})$ than deep $(1.4 \mathrm{~mm})$, incompletely divided dorsally by a median Yshaped rostral groove, bordered posterodorsally by three granules, of which the central scale bears a suture; nostril bordered anteriorly by 
rostral, dorsally by one anterior supranasal, posteriorly by three nasals, and ventrally by first supralabials.

Supralabials, nine (both sides); eight infralabials (both sides), first three largest; scales of rostrum, lores, crown, and occiput small and granular, occiput with few small tubercles; mental triangular, as wide $(2.3 \mathrm{~mm})$ as deep $(2.2$ $\mathrm{mm})$, bordered anterolaterally by first infralabials and posteriorly by paired elongate primary postmentals that contact posteriomedially for $40 \%$ of their length; postmentals bordered by two enlarged chin shields and five small gular scales, the chin shields arranged in one row grading posteriorly into smaller scales and extending posteriorly to the sixth infralabial; gular scales small and granular, grading posteriorly into slightly larger, flatter, throat scales, then into large, flat, imbricate pectoral and abdominal scales.

Body relatively short (AGL/SVL 0.18) with weak ventrolateral folds bearing scattered tubercles; dorsal scales small, granular, interspersed with relatively high, trihedral, rounded tubercles that are arranged in 18 irregular rows at midbody; smallest tubercles on flanks and in the frontal region; 29 paravertebral tubercles at midbody; ventral scales much larger than dorsal scales; 42 flat, imbricate ventral scales at midbody between ventrolateral folds; precloacal region with six rows of enlarged scales; 43 femoro-precloacal pores in continuous row; two rows of enlarged femoral scales anterior to pores, twice larger than the next anterior, then becoming slightly smaller in more anterior rows .

Forelimbs short (FAL/SVL 0.15); granular scales of forearms similar those of body; a few tubercles on dorsal base of lower arm; palmar scales slightly raised, smaller anteriorly than posteriorly; digits short, with inflection at basal inter-phalangeal joints; subdigital lamellae transversely expanded proximal to joint inflections, digits narrow distal to joints; claws well-developed, sheathed by a dorsal and ventral scale; subdigital lamellae on digits of manus: I (12), II (13), III (15), IV (15), V (13), relative lengths of manual digits: IV $>$ V $>$ III $>$ II $>$ I.

Hind limbs more robust than forelimbs, tibia relatively long (TBL/SVL 0.20), covered dorsally with granular scales interspersed with tubercles; ventral hind limb scales flat, larger than dorsal; digits short, subdigital lamellae of pes transversely expanded proximal to inflected joints, digits narrow distal to joints; count of subdigital lamellae on pes: I (12), II (14), III (16), IV (19), V (16), relative length of pedal digits: IV > V > III > II > I; claws well-developed, sheathed by a dorsal and ventral scale.

Tail original and complete, TL/SVL 1.23, robust at base, tapering to a point; dorsal caudal scales granular with six small tubercles on anterior caudal whorls; four post-cloacal tubercles on each side of vent; subcaudals small, flat, imbricate, smooth, and rounded, lacking enlarged median subcaudals.

Variation. Males have femoro-precloacal pores, while females do not. See Table $1 \& 2$.

Table 1. Morphometric characters of the type series of Cyrtodactylus jatnai sp. nov., measurements are in $\mathrm{mm}$.

\begin{tabular}{|c|c|c|c|c|c|}
\hline \multirow{3}{*}{ Character } & \multirow{3}{*}{$\begin{array}{c}\text { holotype } \\
\begin{array}{c}\text { Adult } \\
\text { male }\end{array}\end{array}$} & \multicolumn{4}{|c|}{ paratypes $(n=18)$} \\
\hline & & \multicolumn{2}{|c|}{ male } & \multicolumn{2}{|c|}{ female } \\
\hline & & $\begin{array}{l}\text { Adult } \\
(n=5)\end{array}$ & $\begin{array}{c}\text { Subadult } \\
(n=6)\end{array}$ & $\begin{array}{l}\text { Adult } \\
(n=4)\end{array}$ & $\begin{array}{c}\text { Subadult } \\
(n=3)\end{array}$ \\
\hline snout-vent length (SVL) & 66.8 & $56.3-60.1$ & $47.5-52.4$ & $55.8-64.8$ & $44.2-51.5$ \\
\hline head length (HL) & 19.5 & $16.2-18.2$ & $14.0-15.8$ & $15.3-20.6$ & $14.0-15.4$ \\
\hline head width (HW) & 12.3 & $11.1-13.8$ & $9.3-10.2$ & $10.7-11.9$ & $9.0-10.7$ \\
\hline head depth (HD) & 7.7 & $7.3-8.4$ & $5.6-6.2$ & $6.8-8.2$ & $5.8-6.5$ \\
\hline snout length (ES) & 7.7 & $5.9-7.2$ & $5.8-5.9$ & $6.4-7.7$ & $5.7-6$ \\
\hline eye-nostril length (EN) & 5.5 & $4.1-5.3$ & $4.1-4.6$ & $4.9-5.9$ & $4.0-4.8$ \\
\hline orbit diameter (OD) & 6.3 & $4.2-6.3$ & $3.2-4.6$ & $4.2-6.5$ & $3.2-4.1$ \\
\hline eye to ear distance (TYE) & 4.9 & $4.1-5.6$ & $3.6-3.9$ & $3.8-5.5$ & $3.9-4.4$ \\
\hline tympanum diameter (TYD) & 2.3 & $2.0-2.3$ & $1.3-1.6$ & $1.3-1.9$ & $1.5-1.7$ \\
\hline forearm length (FAL) & 9.9 & $9.0-10.0$ & $7.2-8.1$ & $8.7-10.0$ & $6.8-7.9$ \\
\hline femur length (FEL) & 12.2 & $11.0-11.8$ & $9.3-11.0$ & $10.5-12.2$ & $9.1-10.0$ \\
\hline tibia length (TBL) & 12.1 & $10.8-11.4$ & $9.1-10.6$ & $10.2-12.0$ & $8.9-9.7$ \\
\hline tail length (TL) & 82.5 & $60.6-82.5$ & $61.4-67.8$ & $58.8-72.3$ & $43.3-53.7$ \\
\hline
\end{tabular}




\section{Plate 22}
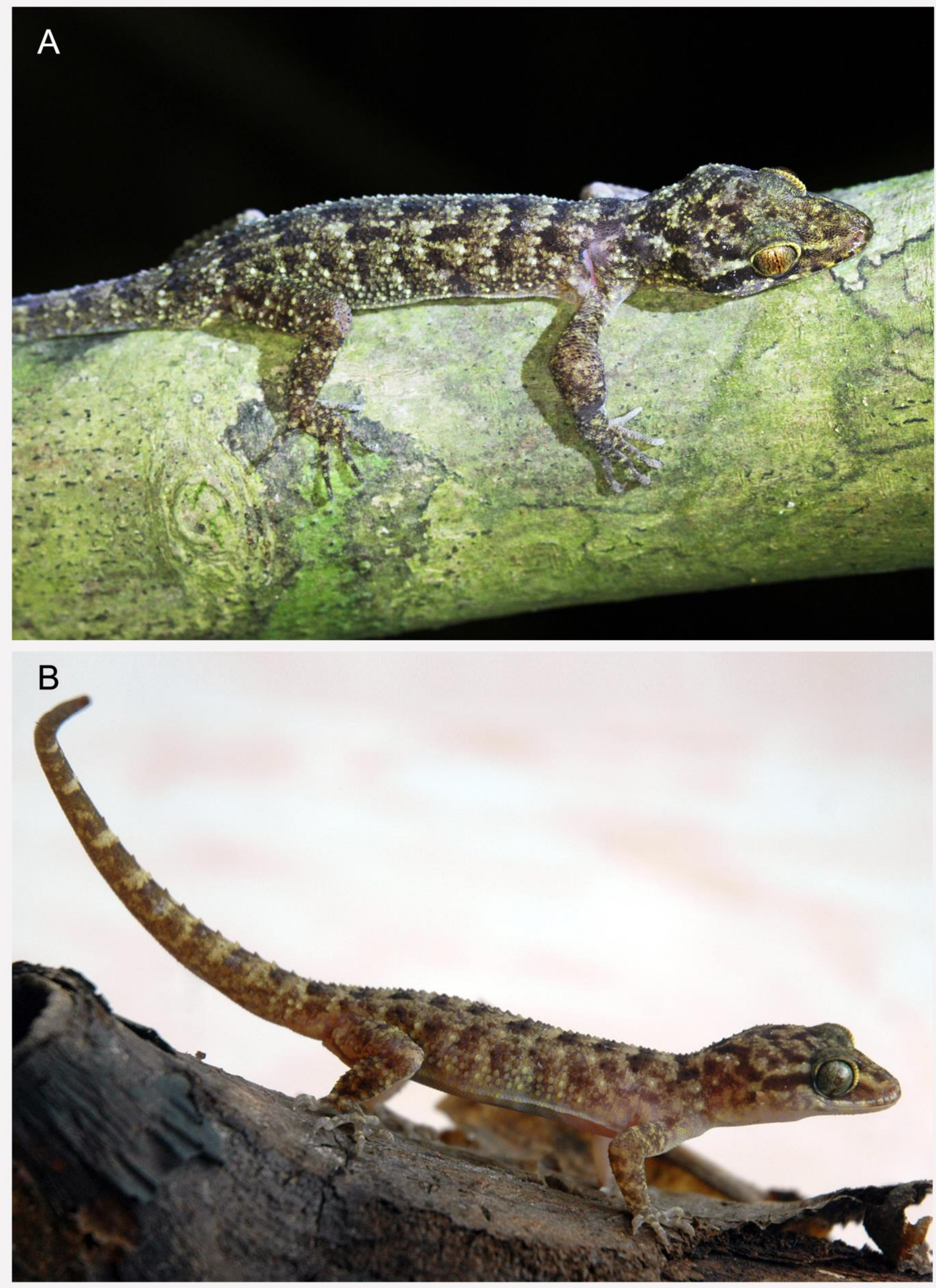

Figure 1. Cyrtodactylus jatnai sp. nov. (A) adult male (holotype, UIMZ 0085) from Teluk Menjangan, Taman Nasional Bali Barat, Indonesia. Photograph (C A.A. Thasun Amarasinghe; (B) adult male (paratype, MZB 8729) from Teluk Terima, Taman Nasional Bali Barat, Indonesia. Photograph @ Awal Riyanto. 


\section{Plate 23}

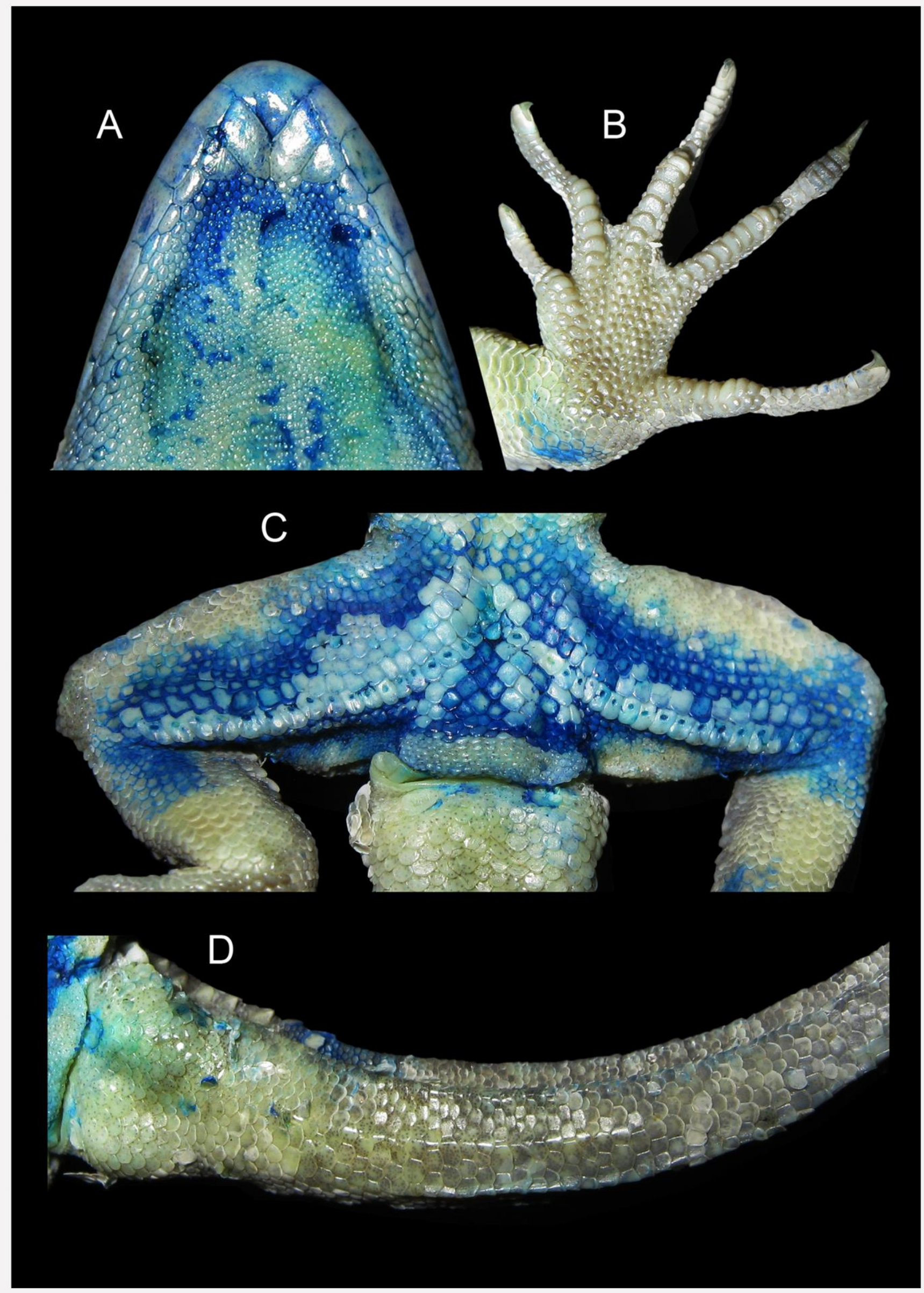

Figure 2. Cyrtodactylus jatnai sp. nov., paratype (MZB 8729), ventral aspect of the (A) anterior head, (B) foot, (C) femur, and (D) tail. Photograph (C) A.A. Thasun Amarasinghe. 
Table 2. Meristic characters of the type series of Cyrtodactylus jatnai sp. nov.

\begin{tabular}{|c|c|c|c|c|c|}
\hline \multirow{3}{*}{ Character } & \multirow{3}{*}{$\begin{array}{c}\text { holotype } \\
\text { Adult } \\
\text { male }\end{array}$} & \multicolumn{4}{|c|}{ paratypes $(n=18)$} \\
\hline & & \multicolumn{2}{|c|}{ male } & \multicolumn{2}{|c|}{ female } \\
\hline & & $\begin{array}{l}\text { Adult } \\
(n=5)\end{array}$ & $\begin{array}{c}\text { Subadul } \\
\mathrm{t}(n=6)\end{array}$ & $\begin{array}{l}\text { Adult } \\
(n=4)\end{array}$ & $\begin{array}{c}\text { Subadult } \\
(n=3)\end{array}$ \\
\hline Supralabials (Right / Left) & $9 / 9$ & $9 / 9$ & $9 / 9,10$ & $9,10 / 9,10$ & $9,11 / 9,10$ \\
\hline Infralabials (Right / Left) & $8 / 8$ & $8 / 8$ & $8,9 / 8,9$ & $7,8 / 7,8$ & $8,9 / 8$ \\
\hline Dorsal tubercle rows & 18 & 17,18 & 18,19 & 17,18 & 18 \\
\hline Paravertebral tubercles & 29 & $24-26$ & $27-29$ & $24-28$ & $26-29$ \\
\hline Ventral scales between ventrolateral folds & 42 & $44-46$ & $40-44$ & $40-48$ & $40-45$ \\
\hline Postcloacal spur & 4 & 3,4 & 3,4 & 3,4 & 3 \\
\hline Lamella on finger IV & 16 & 15,16 & 15,16 & 15,16 & $15-17$ \\
\hline Lamella on toe IV & 19 & $17-19$ & $17-19$ & 17,18 & $17-19$ \\
\hline Enlarged femoro-precloacal scales & 43 & $40-44$ & $38-43$ & $38-42$ & $40-43$ \\
\hline Femoro-precloacal pores & 43 & $40-43$ & $40-43$ & 0 & 0 \\
\hline
\end{tabular}

Coloration in life. Dorsum yellowish brown with dark blotches; eight pairs of dark square blotches on the trunk; paired dark blotches form a V-shaped marking on occiput; a dark line extends from posterior margin of nares to the anterior supracliliaris, interrupted by eyes, then continues to the ear opening and is interrupted by yellowish blotches above the ear; labials greyish bearing yellow and brown blotches; paravertebral blotches extend from nape to base of the tail; dark body blotches extend to tail where light countershading transforms into cream-colored bands which do not encircle the tail, 16 dark bands on the tail; tubercles on lateral fold and two or three series of tubercles adjacent lateral folds are yellowish. Venter white stippled with gray; subcaudals darkened with fine mottling; iris golden in color.

Etymology. The specific epithet is a noun in the genitive singular case, honoring a leading conservationist, ecologist, and primatologist Prof. Jatna Supriatna (University of Indonesia) for his enormous contributions to biodiversity conservation in Indonesia, as well as his generous friendship and support of the first author. Prof. Supriatna was born on Bali where the new species was discovered. His valuable contributions to science, policy making, and conservation management, as well as to popularizing the conservation ethic among his students and the general public are highly commendable. He is a legend in the field of conservation and locally he is known as "The Noah of Modern History". The NGO, Conservation International, has called him "the Conservation Warrior of Indonesia". English Name: Jatna's bent-toed gecko.

Natural history. Specimens were collected dduring day and night in a variety of habitat types such as wet tropical and monsoon forests, dry deciduous forests, coral outcrops near the beach, rock boulders near rivers, and shrubs near the beach (Fig. 3) at 20-130 m a.s.l. All were observed below $3 \mathrm{~m}$ above the ground level. The holotype was collected at 19:00 $\mathrm{h}$ while on a tree trunk $50 \mathrm{~cm}$ above ground level, near the beach.

Comparison. Cyrtodactylus jatnai sp. nov. is most similar to the following species: $C$. batucolus Grismer, Chan, Grismer et al., 2008; C. darmandvillei (Weber, 1890); C. jellesmae (Boulenger, 1897); C. kimberleyensis Bauer \& Doughty, 2012; C. petani Riyanto, Grismer \& Wood, 2015a; C. sadleiri (Wells \& Wellington, 1985); and C. seribuatensis Youmans \& Grismer, 2006. However, the new species differs from them by characters listed in Table 3 .

In addition, among the other similar species, the new species is distinguished from Cyrtodactylus metropolis Grismer, Wood, Onn et al., 2014, by having 24-29 paravertebral tubercles (vs 32-34), 17-19 lamellae on the fourth toe (vs 20-21), and femoro-precloacal pores ( $v s$ poreless) in males; from $C$. majulah Grismer, Wood \& Lim, 2012 by having 24-29 paravertebral tubercles ( $v s$ 39-46), and 40-43 femoro-precloacal pores ( $v s$ no femoral pores and 7-11 precloacal pores) in males; from $C$. pantiensis Grismer, Chan, Grismer et al., 2008 and C. payacola Johnson, Quah, Anuar et al., 2012 together by having 40-43 femoroprecloacal pores ( $v s$ no femoral pores and 8-12 precloacal pores) in males; from $C$. psarops Harvey, O'Connell, Barraza et al., 2015 and $C$. semicinctus Harvey, O'Connell, Barraza et al., 2015 together by having 40-43 femoroprecloacal pores (vs 28-38) in males; from $C$. rosichonariefi (sic) Riyanto, Grismer \& Wood, 2015a by having 40-43 femoro-precloacal pores ( $v s$ poreless) in males; from $C$. semenanjungensis Grismer \& Leong, 2005 by 
having 24-29 paravertebral tubercles (vs 32-37), blotched dorsal color pattern ( $v s$ banded), and femoro-precloacal pores ( $v s$ poreless) in males; from $C$. tiomanensis Das \& Lim, 2000 by having 40-48 ventral scale rows (vs 36-40), 17-19 lamellae on the fourth toe (vs 20-22), and 40-43 femoro-precloacal pores (vs 3-5 precloacal pores).

Furthermore, we compared the new species to the recognized Melanesian and Wallacean species. The new species is easily distinguished from C. agamensis (Bleeker, 1860) by having 40-48 ventral scale rows (vs 67), and 17-19 lamellae on the fourth toe ( $v s$ 26); from $C$. batik Iskandar, Rachmansah \& Umilaela, 2011 by a much smaller SVL $66.8 \mathrm{~mm}$ (vs $110 \mathrm{~mm}$ ) and by having 40-48 ventral scale rows ( $v s$ 48-57), blotched dorsal color pattern ( $v s$ banded), and 40-43 femoro-precloacal pores ( $v s$ poreless) in males; from C. baluensis (Mocuard, 1890) by lacking enlarged transverse median subcaudals ( $v s$ enlarged) and by having 40-43 femoroprecloacal pores (vs 9-11 femoral pores and 410 precloacal pores) in males; from $C$. cavernicolus Inger \& King, 1961 by having 4048 ventral scale rows (vs 51-58), 17-19 lamellae on the fourth toe ( $v s$ 22-26), blotched dorsal color pattern ( $v s$ banded), and 40-43 femoroprecloacal pores ( $v s$ no femoral pores and 4 precloacal pores) in males; from $C$. celatus Kathriner, Bauer, O'Shea et al., 2014 in being much larger SVL $66.8 \mathrm{~mm}$ (vs $38.4 \mathrm{~mm}$ ) and by having 24-29 paravertebral tubercles (vs

Table 3. Selected diagnostic characters separating Cyrtodactylus jatnai sp. nov. from the species of the Cyrtodactylus darmandvillei complex; "_," not applicable, "?" unknown.

\begin{tabular}{|c|c|c|c|c|c|c|c|c|}
\hline Charcter & $\begin{array}{l}\dot{0} \\
0 \\
\dot{0} \\
0 \\
\vec{\vdots} \\
\vdots \\
.0\end{array}$ & 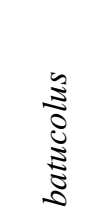 & 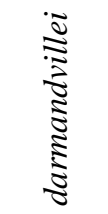 & 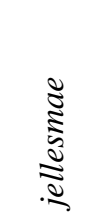 & 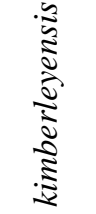 & 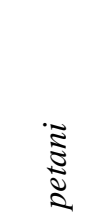 & 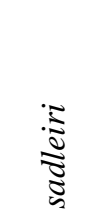 & 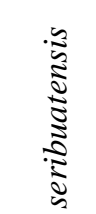 \\
\hline Maximum SVL (in mm) & 66.8 & 75.2 & 75.0 & 63.0 & 45.0 & 57.2 & 88.0 & 75.0 \\
\hline Supralabials & $9-11$ & $9-11$ & 12 & $10-12$ & 9,10 & 9,10 & $9-13$ & $8-13$ \\
\hline Infralabials & 8,9 & $9-11$ & 9,10 & 10,11 & 9,10 & 7,8 & $8-10$ & $7-10$ \\
\hline Tubercles on head & yes & yes & yes & yes & no & yes & yes & yes \\
\hline No. of paravertebral tubercles & $24-29$ & $30-35$ & $?$ & $?$ & $?$ & $20-25$ & $22-25$ & $29-35$ \\
\hline Tubercles on lateral skin fold & yes & $?$ & yes & no & yes & no & no & no \\
\hline No. of ventral scale rows & $40-48$ & $38-45$ & $36-40$ & $40-45$ & 36 & $30-35$ & $34-42$ & $28-39$ \\
\hline Deep precloacal grove & no & no & no & no & no & no & yes & no \\
\hline No. of precloacal pores & - & - & $?$ & 0 & $?$ & - & $8-13$ & $10-12$ \\
\hline Enlarged precloacal scales & - & - & $?$ & $?$ & $?$ & - & yes & yes \\
\hline No. of femoral pores & - & - & $?$ & 0 & $?$ & - & $9-16$ & $14-16$ \\
\hline Enlarged femoral scales & - & - & $?$ & $?$ & $?$ & - & yes & yes \\
\hline No. of femorocloacal pores & $40-43$ & $43-46$ & $?$ & - & $?$ & $31-35$ & - & - \\
\hline Enlarged femorocloacal scales & yes & yes & $?$ & - & $?$ & yes & - & - \\
\hline Tubercles on forelimbs & no & yes & yes & yes & no & yes & yes & yes \\
\hline Tubercles on hind limbs & yes & yes & yes & yes & no & yes & yes & yes \\
\hline $4^{\text {th }}$ toe lamellae & $17-19$ & $17-19$ & $?$ & $?$ & 16 & $17-18$ & $19-24$ & $17-22$ \\
\hline Tubercles on upper side of tail & yes & yes & yes & yes & no & yes & yes & yes \\
\hline Enlarged median subcaudal scales & no & no & yes & no & no & no & no & no \\
\hline No. of light bands in original tail & $11-13$ & $14-16$ & $?$ & $?$ & 11 & $20+$ & $?$ & $13-15$ \\
\hline Distribution & 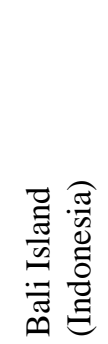 & 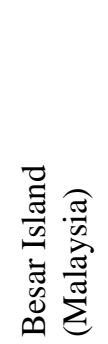 & 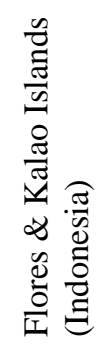 & 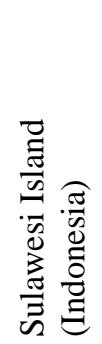 & 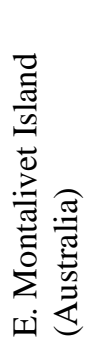 & 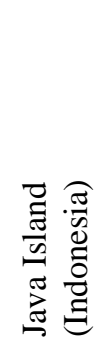 & 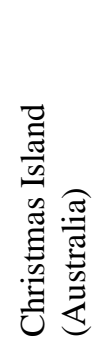 & 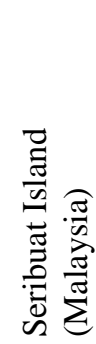 \\
\hline
\end{tabular}




\section{Plate 24}
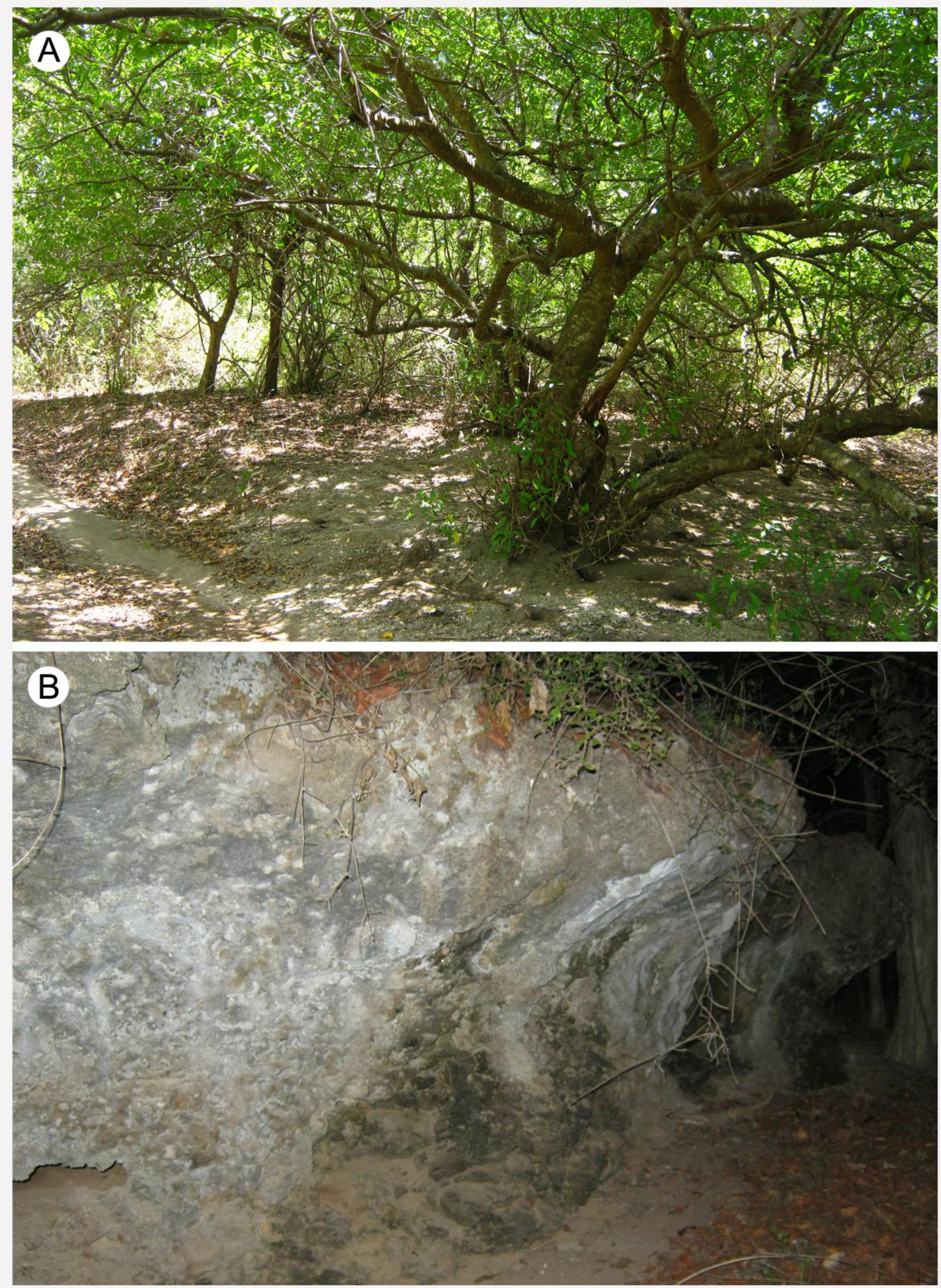

Figure 3. Habitats of Cyrtodactylus jatnai sp. nov. at Taman Nasional Bali Barat, Indonesia, (A) a dry monsoon and savannah forest near the beach (the holotype locality) and (B) a coral outcrop near the beach. Photograph (C) A.A. Thasun Amarasinghe 
16 ), and 40-43 femoro-precloacal pores ( $v s$ no femoral pores and four precloacal pores) in males; from $C$. consobrinus (Peters, 1871) in being much smaller SVL $66.8 \mathrm{~mm}$ (vs $121 \mathrm{~mm}$ ) and by having 40-48 ventral scale rows ( $v s$ 5865), 17-19 lamellae on the fourth toe (vs 23-28), blotched dorsal color pattern ( $v s$. banded), and 40-43 femoro-precloacal pores ( $v s$ 1-6 femoral pores and 9-10 precloacal pores separately) in males; from $C$. deveti (Brongersma, 1948) in being much smaller SVL $66.8 \mathrm{~mm}$ ( vs $106 \mathrm{~mm}$ ), and by lacking enlarged transverse median subcaudals ( $v s$ enlarged); from $C$. fumosus (Müller, 1895) by having 40-48 ventral scale rows (vs 35-40), 17-19 lamellae on the fourth toe (vs 20-22), tubercles along ventrolateral fold (vs absent), and 40-43 femoro-precloacal pores (vs 6 femoral pores and 10 precloacal pores separately) in males; from C. gordongekkoi (Das, 1994) by having 17-19 lamellae on the fourth toe ( $v s$ 20-23), 40-48 ventral scale rows (vs 30-32), and 40-43 femoro-precloacal pores (vs no precloacal pores) in males; from $C$. gunungsenyumensis Grismer, Wood, Anuar et al., 2016 by having 24-29 paravertebral tubercles ( vs 34-40), 40-48 ventral scale rows (vs 38-41), 17-19 lamellae on the forth toe (vs 20-23), and 40-43 femoro-precloacal pores (vs poreless) in males; from $C$. halmahericus (Mertens, 1929) by having 40-43 femoroprecloacal pores (vs 48-53) in males; from $C$. hikidai Riyanto, 2012 in being much smaller SVL $66.8 \mathrm{~mm}$ (vs $100 \mathrm{~mm}$ ) and by having 1719 lamellae on the fourth toe (vs 22-24), and 40-43 femoro-precloacal pores ( $v s$ no femoral pores and 6 precloacal pores) in males; from $C$. hitchi Riyanto, Kurniati \& Engilis, 2016 by lacking enlarged transverse median subcaudals ( vs enlarged), blotched dorsal color pattern ( $v s$ banded), and by having 40-43 femoroprecloacal pores ( $v s$ poreless) in males; from $C$. klakahensis Hartmann, Mecke, Kieckbusch, 2016 by having 40-43 femoro-precloacal pores (vs 37-38) with two rows of enlarged precloacofemoral scales ( $v s$ three) in males; from C. laevigatus Darevsky, 1964 in being much larger SVL $66.8 \mathrm{~mm}$ (vs $38.5 \mathrm{~mm}$ ) and by having 40-48 ventral scale rows (vs 30-3), 1719 lamellae on the fourth toe ( $v s$ 10-15), and femoro-precloacal pores ( $v s$ no femoral pores) in males; from $C$. lateralis (Werner, 1896) by having 40-48 ventral scale rows (vs 60-64), 1719 lamellae on the fourth toe (vs 21-22), and 40-43 femoro-precloacal pores ( $v s$ no femoral pores and 13 precloacal pores) in males; from $C$. malayanus (De Rooij, 1915) by having 40-48 ventral scale rows (vs 58-62), 17-19 lamellae on the fourth toe (vs 21-23), blotched dorsal color pattern ( $v s$ banded), and 40-43 femoroprecloacal pores ( $v s$ no femoral pores and $8-10$ precloacal pores) in males; from C. marmoratus Gray, 1831 by having $40-43$ femoro-precloacal pores ( $v s$ 45-53) in males; from $C$. nuaulu Oliver, Edgar, Mumpuni et al., 2009 by having 40-43 femoro-precloacal pores ( $v s$ no femoral pores) in males; C. papuensis Brongersma, 1934 by lacking deep groove-like precloacal depression ( $v$ s present); from $C$. pubisulcus Inger, 1958 by having 40-43 femoro-precloacal pores ( $v s$ no femoral pores and 7-9 precloacal pores) in males; from C. quadrivirgatus Taylor, 1962 by having $40-48$ ventral scale rows (vs 3442 ), and 40-43 femoro-precloacal pores ( $v s$ poreless or 1-4 precloacal pores) in males; from C. semenanjungensis Grismer \& Leong, 2005 by having 40-48 ventral scale rows (vs 48-53), and 40-43 femoro-precloacal pores ( $v s$ poreless) in males; from $C$. semiadii Riyanto, Bauer \& Yudha, 2014 in being much larger SVL 66.8 $\mathrm{mm}(v s 47.1 \mathrm{~mm})$ and by having $40-43$ femoroprecloacal pores ( $v s$ poreless) in males; from $C$. spinosus Linkem, McGuire, Hayden et al., 2008 by lacking spine-like tubercles on dorsum ( $v s$ present) and by having 40-43 femoro-precloacal pores ( $v s$ no femoral pores and 12-13 precloacal pores) in males; from C. stresemanni Rösler \& Glaw, 2008 by having $9-11$ supralabials (vs 13), 40-48 ventral scale rows (vs 63), blotched dorsal color pattern ( $v s$ striped); from $C$. tahuna Riyanto, Arida \& Koch, 2018a by having 40-48 ventral scale rows ( $v s 49-50), 17-19$ lamellae on the forth toe ( $v s$ 20-24), and 40-43 femoroprecloacal pores ( $v s 5$ femoral pores and 14 precloacal pores) in males; from C. tambora Riyanto, Mulyadi, McGuire et al., 2017 in being much larger SVL $66.8 \mathrm{~mm}(v s 47.4 \mathrm{~mm}$ ) and by having 40-43 femoro-precloacal pores ( $v s$ no femoral pores and 5-6 precloacal pores) in males; from C. tanahjampea Riyanto, Hamidy \& McGuire, 2018b by having 24-29 paravertebral tubercles (vs 31-34), and 40-48 ventral scale rows (vs 29-34), and 40-43 femoro-precloacal pores (vs 28-34); from C. wallacei Hayden, Brown, Gillespie et al., 2008 in being much smaller SVL $66.8 \mathrm{~mm}$ ( $v \mathrm{~s} 114 \mathrm{~mm}$ ) and by lacking enlarged transverse median subcaudals ( $v s$ enlarged), and by having 40-43 femoroprecloacal pores ( $v s$ poreless) in males; from $C$. 
wetariensis (Dunn, 1927) by having 17-19 lamellae on the forth toe (vs 20-22) and 40-43 femoro-precloacal pores (vs 12-16 femoral pores and 5-6 precloacal pores) in males.

Finally, the new species differs from $C$. boreoclivus, C. cavernicolus, C. elok, C. equitris, C. ingeri, C. matsuii, C. sermowaensis, and $C$. yoshii by having enlarged femoroprecloacal sclaes ( $v s$ not enlarged); from $C$. durio, and $C$. jarakensis by possessed an abrupt transition between rows of large and small postfemoral and ventral femoral scales (vs absent); from $C$. astrum, $C$. aurensis, $C$. australotitiwangsaensis $C$. bintangrendah, $C$. bintangtinggi, C. brevipalmatus, C. leegrismeri, C. lengkawiensis, C. macrotubercularus, $C$. peguensis, $C$. pulchellus, $C$. rex, and $C$. trilatofasciatus by lacking transversely enlarged median subcaudals ( $v s$ enlarged).
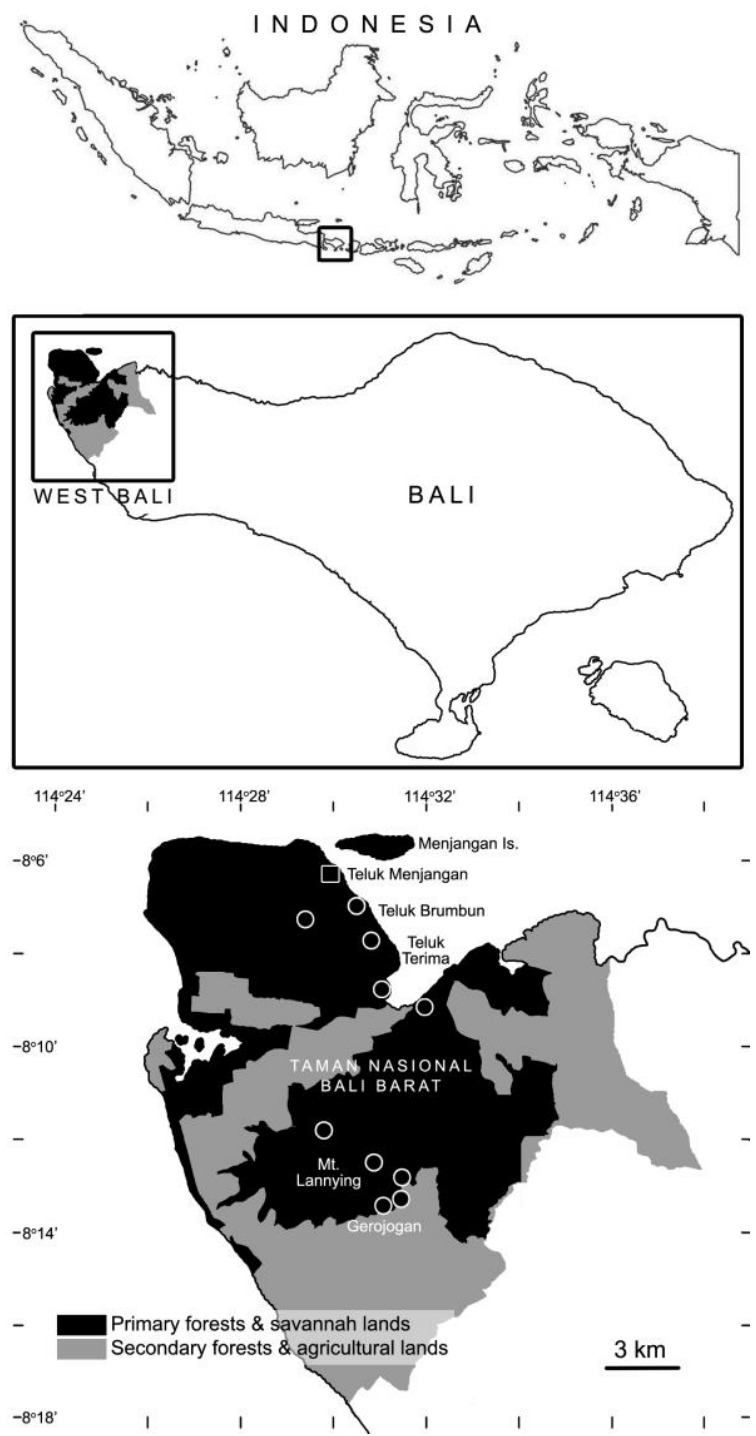

Figure 4. Distribution map of Cyrtodactylus jatnai sp. nov. in Bali Island; the holotype locality is marked with a square symbol.

\section{Discussion}

Current phylogenetic hypotheses of SE Asian Cyrtodactylus of the C. sworderi group are based on molecular data (Grismer et al. 2014) and the morphological placement of $C$. jatnai sp. nov. close to $C$. seribuatensis from Pulau Seribuat, West Malaysia suggests a relationship of the Bali population with Peninsular Malaysian populations rather than the other Greater Sundaic Island populations.

Cyrtodactylus rosichonariefi (sic) was described by Riyanto, Grismer \& Wood (2015a) who placed the specific epithet "rosichonariefi" an eponym, as a noun in the genitive case adding the suffix $[-i]$ directly to the stem of a modern personal name, in a case if the personal name is that of a man. However according to the etymology stated the species epithet was formed in case of men: (i) Rosichon Ubaidillah and (ii) Ahmad Jauhar Arief. Therefore the epithet "rosichonariefi" used by Riyanto et al. (2015a), is improperly constructed and, and the correct epithet would be "rosichonarieforum", adding the suffix [-orum].

Cyrtodactylus jatnai sp. nov. is the only Cyrtodactylus reported from West Bali and is endemic to that Island. It will be interesting to know if congeners occur in eastern parts of Java or if these geckos have crossed the relatively narrow Bali Strait to Java. Answering these questions will require additional fieldwork in the many poorly explored parts of eastern Java. We assume that more surveys and comprehensive taxonomic studies will increase the known biodiversity of Bali Island, as well as the evolutionary position of Bali's fauna in relation to Sundaland and Lesser Sunda.

\section{Acknowledgements}

We thank the Ministry of Research and Technology of the Republic of Indonesia, particularly S. Wahyono and L. Shalahuddin for granting research permits to AATA. Also we thank the Ministry of Environment and Forestry (KLHK) and The Directorate General of Conservation of Natural Resources and Ecosystems (KSDAE) of the Republic of Indonesia for granting research and collecting permits to AATA. We would like to thank Tedi Sutedi (Head of West Bali National Park) and all the staff of West Bali National Park for providing all the support and facilities, and granting permits during the research as a collaborative party of the research. R. Ubaidillah, A. Hamidy, Syaripudin, W. 
Trilaksana and other staff members of MZB for facilitating in-house study of specimens under their care. We thank to Mulyadi, J.M.A. Ginting, C. Adha Putra, and D.F. Ekarini for their assistance during fieldwork, Maharadatunkamsi, Eko Sulistyadi and Nanang for the support. Fieldwork conducted by Riyanto and Mumpuni in Bali Barat National Park was funded by Indonesian Government via project of PKPPDIKTI LIPI 2012 (Contract No: 006/PPK/Kontrak/PKPP/AD.IM/II /2012). Fieldwork conducted by Amarasinghe and party in West Bali National Park was funded by USAID University Partnership Program under the "Strengthening Indonesia's Climate Change Mitigation Capacity Program" (Agreement No. AID-497-1-12-00009; March 2012 - December 2015) partnership with Research Center for Climate Change at University of Indonesia (PI: Jatna Supriatna) and Center for Environment, Economy, and Society at Columbia University (PI: Don Melnick). The research was conducted as a part of a demonstration project for "The Rainforest Standard ${ }^{\mathrm{TM}}$ (The RFS' ${ }^{\mathrm{TM}}$ ), developed in 2012 by Columbia University's Center for Environment, Economy, and Society; Bolivia's PUMA Environmental Fund Foundation; Brazil's Fund for Biodiversity; Colombia's Environmental Action Fund; Ecuador's National Environmental Fund; Peru's Trust Fund for National Parks and Protected Areas. J. Ramadhan and C. Adha Putra are acknowledged for taking excellent photographs. Aaron Bauer (Villanova University) and Hinrich Kaiser are acknowledged for valuable comments reviewing the manuscript, and Peter Uetz (Reptile Database) for providing some literature. Finally, we would like to thank J. Supriatna, N.L. Winarni, A.A. Dwiyahreni, Maya Dewi, D. Hartiningtias, and the staff of the Research Center for Climate Change, University of Indonesia, for their support.

\section{Literature cited}

Amarasinghe, A.A.T., M.B. Harvey, A. Riyanto, and E.N. Smith (2015). A new species of Cnemaspis (Reptilia: Gekkonidae) from Sumatra, Indonesia. Herpetologica, 71 (2): 160-167.

Amarasinghe, A.A.T., N.A. Poyarkov Jr, P.D. Campbell, S. Leo, J. Supriatna et al. (2017). Systematics of Eutropis rugifera (Stoliczka, 1870) (Squamata: Scincidae) including the redescription of the holotype. Zootaxa 4272 (1): 103-118.
Barbour, T. (1912). A contribution to the zoogeography of the East Indian Islands. Memoirs of the Museum of Comparative Zoology at Harvard College, 44 (1): 203 pp.

Bauer, A.M. and P. Doughty (2012). A new benttoed gecko (Squamata: Gekkonidae: Cyrtodactylus) from the Kimberley region, Western Australia. Zootaxa, 3187: 32-42.

Bauer, A.M., K. Kunya, M. Sumontha, P. Niyomwan, O.S.G. Pauwels et al. (2010). Cyrtodactylus dumnuii (Squamata: Gekkonidae), a new cave-dwelling gecko from Chiang Mai Province, Thailand. Zootaxa, 2570, 41-50.

Beccaloni, G.W. (2015). Alfred Russel Wallace and natural selection: the real story. In: Supriatna, J., A.A.T. Amarasinghe \& C. Margules (eds.). Proceedings of the Second International Conference on Alfred Russel Wallace and the Wallacea organised by the Indonesian Academy of Sciences. Wakatobi Indonesia, 10-13 November 2013. Taprobanica, 7 (3), (Alfred Russel Wallace Centenary Issue): I-X pp.

Berlianty, D. and T. Yanagi (2011). Tide and tidal current in the Bali Strait, Indonesia. Marine Research in Indonesia, 36 (2): 25-36.

Bleeker, P. (1860). Reptilien van Agam. Natuurkundig Tijdschrift voor Nederlandsch Indie, Batavia, 20 (6): 325-329.

Boulenger, G.A. (1897). A catalogue of the reptiles and batrachians of Celebes with special reference to the collections made by Drs. P \& F Sarasin in 1893-1896. Proceedings of the Zoological Society London: 193-237.

Brongersma,L.D. (1934). Contributions to IndoAustralian herpetology. Zoologische Mededelingen, 17 (9): 161-251.

Brongersma, L.D. (1948). Lizards from the island of Morotai (Moluccas). Proceedings van de Koninklijke Nederlandse Akademie van Wetenschappen Section C, 51 (4): 486-495.

Darevsky, I.S. (1964). Die Reptilien der Inseln Komodo, Padar und Rintja im Kleinen SundaArchipel, Indonesien. Senckenbergiana biologica, 43 (5): 563-576.

Das, I. (1994). Cnemaspis gordongekkoi, a new gecko from Lombok, Indonesia, and the biogeography of oriental species of Cnemaspis (Squamata: Sauria: Gekkonidae). Hamadryad, 18 (1): $1-9$.

Das, I. and L.J. Lim (2000). A new species of Cyrtodactylus (Sauria: Gekkonidae) from Pulau Tioman. The Raffles Bulletin of Zoology, 48 (2): 223-231.

de Rooij, N. de (1915). The Reptiles of the IndoAustralian Archipelago, volume I: Lacertilia, 
Chelonia, Emydosauria. Leiden E. J. Brill: 384 pp.

Dunn, E.R. (1927). Result of the Douglas Burden Expedition to the Island of Komodo, volume III: Lizards from the East Indies. American Museum Novitates, 288: 1-13.

Gray, J.E. (1831). A synopsis of the species of Class Reptilia. In: Griffith, E. \& E. Pidgeon (eds.): The animal kingdom arranged in conformity with its organisation by the Baron Cuvier with additional descriptions of all the species hither named, and of many before noticed. V Whittaker, Treacher and Co. London: $481+110 \mathrm{pp}$.

Grismer, L.L. and T.M. Leong (2005). New Species of Cyrtodactylus (Squamata: Gekkonidae) from Southern Peninsular Malaysia. Journal of Herpetology, 39 (4): 584-591.

Grismer, L.L., C.K. Onn, J.L. Grismer, P.L. Wood, and D. Belabut (2008). Three new species of Cyrtodactylus (Squamata: Gekkonidae) from Peninsular Malaysia. Zootaxa, 1921: 1-23.

Grismer, L.L., P.L. Wood Jr, and K.K.P. Lim (2012). Cyrtodactylus majulah, a new species of bent-toed gecko (Reptilia: Squamata: Gekkonidae) from Singapore and the Riau Archipelago. The Raffles Bulletin of Zoology, 60 (2): 487-499.

Grismer, L.L., P.L. Wood Jr., CK. Onn, S. Anuar, and M.A. Muin (2014) Cyrts in the city: a new bent-toed gecko (genus Cyrtodactylus) is the only endemic species of vertebrate from Batu Caves, Selangor, Peninsular Malaysia. Zootaxa, 3774 (4), 381-394.

Grismer, L.L., P.L. Wood Jr., S. Anuar, H.R. Davis, A.J. Cobos et al. (2016). A new species of karst forest bent-toed gecko (genus Cyrtodactylus Gray) not yet threatened by foreign cement companies, and a summary of Peninsular Malaysia's endemic karst forest herpetofauna and the need for its conservation. Zootaxa, 4061 (1): 1-17.

Hartmann, L., S. Mecke, M. Kieckbusch, F. Mader, and H. Kaiser (2016). A new species of bent-toed gecko, genus Cyrtodactylus Gray, 1827 (Reptilia: Squamata: Gekkonidae), from Jawa Timur Province, Java, Indonesia, with taxonomic remarks on $C$. fumosus (Müller, 1895). Zootaxa, 4067 (5): 552-568.

Harvey, M.B., K.A. O’Connell, G. Barraza, A. Riyanto, N. Kurniawan et al. (2015). Two new species of Cyrtodactylus (Squamata: Gekkonidae) from the Southern Bukit Barisan Range of Sumatra and an estimation of their phylogeny Zootaxa, 4020 (3): 495-516.
Hayden, C.J., R.M. Brown, G. Gillespie, M.I. Setiadi, C.W. Linkem et al. (2008) A new species of bent-toed gecko Cyrtodactylus Gray, 1827, (Squamata: Gekkonidae) from the island of Sulawesi, Indonesia. Herpetologica, 64 (1), 2008, 109-120.

Huxley, T.H. (1868). On the Classification and Distribution of the Alectoromorphae and Heteromorphae. Proceedings of the Zoological Society of London: 294-319.

Inger, R.F. (1958). A new gecko of the genus Cyrtodactylus, with a key to the species from Bomeo and the Philippine Islands. Sarawak Museum Journal, Kuching, 8 (2): 261-264.

Inger, R.F. and W. King (1961). A new cavedwelling lizard of the genus Cyrtodactylus from Niah. Sarawak Museum Journal, Kuching, 11 (2): 274-276.

ICZN (1999). International Code of Zoological Nomenclature, $4^{\text {th }}$ edition. International Trust for Zoological Nomenclature, London, UK: $306 \mathrm{pp}$.

Iskandar, D.T., A. Rachmansah, and Umilaela (2011). A new bent-toed gecko of the genus Cyrtodactylus Gray, 1827 (Reptilia, Gekkonidae) from Mount Tompotika, eastern peninsula of Sulawesi, Indonesia. Zootaxa, 2838: 65-78.

Johnson, C.B., S.H.E. Quah, S. Anuar, M.A. Muin, P.L. Wood Jr. et al. (2012). Phylogeography, geographic variation, and taxonomy of the bent-toed gecko Cyrtodactylus quadrivirgatus Taylor, 1962 from Peninsular Malaysia with the description of a new swamp dwelling species. Zootaxa, 3406: 39-58.

Kathriner, A., A.M. Bauer, M. O'Shea, C. Sanchez, H. Kaiser (2014). Hiding in plain sight: a new species of bent-toed gecko (Squamata: Gekkonidae: Cyrtodactylus) from West Timor, collected by Malcolm Smith in 1924. Zootaxa, 3900 (4): 555-568.

Linkem, C.W., J.A. McGuire, C.J. Hayden, M.I. Setiadi, D.P. Bickford et al. (2008). A new species of bent-toed gecko (Gekkonidae: Cyrtodactylus) from Sulawesi Island, Eastern Indonesia. Herpetologica, 64 (2): 224-234.

Marzuki, S. and S. Andili (2015). The Ternate of Alfred Russel Wallace In: Supriatna, J., A.A.T. Amarasinghe \& C. Margules (eds.). Proceedings of the Second International Conference on Alfred Russel Wallace and the Wallacea organised by the Indonesian Academy of Sciences. Wakatobi - Indonesia, 10-13 November 2013. Taprobanica, 7 (3), (Alfred Russel Wallace Centenary Issue): I-X pp. 
McKay, J.L. (2006). Field Guide of the Amphibians and Reptiles of Bali, Krieger Publishing Company, Malabar, Florida: 146 pp.

Mecke, S., L. Hartmann, F. Mader, M. Kieckbusch, and H. Kaiser (2016a). Redescription of Cyrtodactylus fumosus (Müller, 1895) (Reptilia: Squamata: Gekkonidae), with a revised identification key to the bent-toed geckos of Sulawesi. Acta Herpetologica, 11 (2): 151-160.

Mecke, S., M. Kieckbusch, L. Hartmann, and H. Kaiser (2016b). Historical considerations and comments on the type series of Cyrtodactylus marmoratus Gray, 1831, with an updated comparative table for the bent-toed geckos of the Sunda Islands and Sulawesi. Zootaxa, 4175 (4): 353-365.

Mertens, R. (1929). Zwei neue Haftzeher aus dem Indo-Australischen Archipel (Reptiles). Senckenbergiana, 11 (3): 237-241.

Mocquard, F. (1890). Diagnoses d'espèces nouvelles de reptiles et de batraciens des iles Bornèo et Palawan, ser. 2, vol. 4. Le Naturaliste, Paris: 144-145.

Müller, F. (1895). Reptilien und Amphibien aus Celebes, volume II. Bericht. Verhandlungen der Naturforschenden Gesellschaft in Basel, 10: 862-869.

Oliver, P., P. Edgar, Mumpuni, D.T. Iskandar, and R. Lilley (2009). A new species of bent-toed gecko (Cyrtodactylus: Gekkonidae) from Seram Island, Indonesia. Zootaxa, 2115: 4755.

Peters, W. (1871). Über neue Reptilien aus Ostafrika und Sarawak (Borneo), vorzüglich aus der Sammlung des Hrn. Marquis J. Doria zu Genua. Monatsberichte der Königlichen Preussische Akademie des Wissenschaften zu Berlin 1871: 566-581.

Riyanto, A. (2012). Cyrtodactylus hikidai sp. nov. (Squamata: Gekkonidae): a new bent toed gecko from Mount Ranai, Bunguran Island, Indonesia. Zootaxa, 3583: 22-30 [erratum: Zootaxa, 3599 (4): 400].

Riyanto, A. and Mumpuni (2013) Herpetofauna di Taman Nasional Bali Barat. Proseding Seminar Nasional Biologi. 1-7.

Riyanto, A., A.M. Bauer, and D.S. Yudha (2014). A new small karst-dwelling species of Cyrtodactylus (Reptilia: Squamata: Gekkonidae) from Java, Indonesia. Zootaxa, 3785 (4): 589-599.

Riyanto, A., L.L. Grismer, and P.L. Wood Jr (2015a). Cyrtodactylus rosichonariefi sp. nov. (Squamata: Gekkonidae), a new swampdwelling bent-toed gecko from Bunguran
Island (Great Natuna), Indonesia. Zootaxa, 3964 (1): 114-124 [erratum in Zootaxa 3999 (4): 600]

Riyanto, A., L.L. Grismer, and P.L. Wood Jr (2015b). The fourth Bent-toed Gecko of the genus Cyrtodactylus (Squamata: Gekkonidae) from Java, Indonesia. Zootaxa, 4059 (2): 351363.

Riyanto, A., H. Kurniati, and A. Engilis Jr (2016). A new Bent-toed gecko (Squamata: Gekkonidae) from the Mekongga Mountains, South East Sulawesi, Indonesia. Zootaxa, 4109 (1): 59-72.

Riyanto, A., M. Mulyadi, J.A. McGuire, M.D. Kusrini, F. Febylasmia et al. (2017). A new small bent-toed gecko of the genus Cyrtodactylus (Squamata: Gekkonidae) from the lower slopes of Mount Tambora, Sumbawa Island, Indonesia. Zootaxa, 4242 (3): 517-528.

Riyanto, A., E. Arida, and A. Koch (2018a). Cyrtodactylus tahuna sp. nov., a new benttoed gecko (Reptilia: Squamata: Gekkonidae) from Sangihe Island, North Sulawesi, Indonesia. Zootaxa, 4399 (2): 220-232.

Riyanto, A., A. Hamidy, and J.A. McGuire (2018b). A new bent-toed gecko (Cyrtodactylus: Squamata: Gekkonidae) from the Island of Tanahjampea, South Sulawesi, Indonesia. Zootaxa, 4442 (1): 122-136.

Rösler, H. and F. Glaw (2008). A new species of Cyrtodactylus Gray, 1827 (Squamata: Gekkonidae) from Malaysia including a literature survey of mensural and meristic data in the genus. Zootaxa, 1729: 8-22.

Taylor, E.H. (1962). New oriental reptiles. The University of Kansas Science Bulletin, 43 (7): 209-263.

Uetz, P., S. Cherikh, G. Shea, I. Ineich, P.D. Campbell et al. (2019). A global catalog of primary reptile type specimens. Zootaxa, 4695 (5): 438-450.

Wallace, A.R. (1868). The Malay Archipelago. Macmillan and Company, London; Oxford University Press, Fourth impression 1996: 312-318.

Weber, M. (1890). Reptilia from the Malay Archipelago, volume 1: Sauria, Crocodylidae, Chelonia. In: M. Weber M. (ed.). Zoologische Ergebnisse einer Reise in Niederländisch OstIndien, vol. 1. E.J. Brill, Leiden: 158-177 pp.

Wells, R.W. and C.R. Wellington (1985). A classification of the Amphibia and Reptilia of Australia. Australian Journal of Herpetology, Supp. Series (1): 1-61.

Werner, F. (1896). Zweiter Beitrag zur Herpetologie der indo-orientalischen Region. Verhandlungen der Zoologisch-Botanischen 
Gesellschaft in Wien, 46: 6-24.

Whitten, T., R.E. Soeriaitmadja, and S.A. Affi (1996). The ecology of Java and Bali. The ecology of Indonesia series, volume II. Periplus Editions Ltd., Hong Kong: 969 pp.
Youmans, T.M. and L.L. Grismer (2006). A new species of Cyrtodactylus (Reptilia: Squamata: Gekkonodae) from the Seribuat Archipelago, West Malaysia. Herpetological Natural History, 10 (1): 61-70.

Appendix I. Other specimens examined

Cyrtodactylus batucolus (1 ex.): West Malaysia: Besar Island: ZRC 2.6743 (holotype).

C. darmandvillei (3 ex.): Indonesia: Flores: ZMA.RENA 10943-44 (syntypes); Timor: FMNH 154845.

C. fumosus (1 ex.): Indonesia: North Sulawesi: NMB 2662 (holotype).

C. jellesmae (2 ex.): Indonesia: Central Sulawesi: NMB 2660 (lectotype), 2661 (paralectotype).

C. kimberleyensis (1 ex.): Western Australia: WAM R164144 (holotype).

C. petani (13 ex.): Indonesia: East Java: MZB 12899 (holotype), 11706 - 13 (paratypes), 12143 (paratype), 12898-99 (paratypes), 12900 (paratype).

C. sadleiri (1 ex.): Australia: Christmas Island: AMS R95535 (holotype).

C. seribuatensis (10 ex.): West Malaysia: Seribuat Island: ZRC 2.6147 (holotype), 2. 6149-52 (paratypes); Nangka Kecil Island: 2.6148 (paratype); Sibu Island: 2.6153 (paratype); Sibu Tengah Island: 2.6154 (paratype); Mentigi Island: 2.6155 (paratype); Sembilang Island: 2.6156 (paratype).

Published date: 21 May 2020 